\title{
Penerapan Komunikasi Pemasaran terhadap Keputusan Pembelian Konsumen
}

\author{
Rima Rizki Syahputri ${ }^{2}$, Nuri Aslami ${ }^{1}$ \\ Universitas Islam Negeri Sumatra Utara \\ rimarizkisyahputri@gmail.com
}

\begin{abstract}
In the field of marketing, globalization has had a significant impact. Where the market potential is growing, but there is a drawback, namely the increasingly fierce and difficult competition. As a result, marketing in this era of globalization requires more than just producing product improvements, setting lower rates, and distributing goods continuously. Companies, on the other hand, need good marketing communications to promote their products, strengthen their brand image, and generate purchasing decisions. The purpose of this study is to see how the communication mix affects customer purchasing decisions. Advertising, personal selling, sales promotion, direct marketing, and public relations are the five main aspects that make up the marketing communications mix. Where these five parts come together to fulfill the purpose of marketing communication, namely improving product image, which leads to product purchase.
\end{abstract}

Keywords: Marketing, Marketing Communication, Purchasing

\begin{abstract}
ABSTRAK
Dalam bidang pemasaran, globalisasi memberikan dampak yang cukup signifikan. Di mana potensi pasar sedang tumbuh, tetapi ada kekurangannya, yaitu persaingan yang semakin ketat dan sulit. Akibatnya, pemasaran di era globalisasi ini memerlukan lebih dari sekadar menghasilkan peningkatan produk, menetapkan tarif yang lebih murah, dan mendistribusikan barang secara terus-menerus. Perusahaan, di sisi lain, memerlukan komunikasi pemasaran yang baik untuk mempromosikan produk mereka, memperkuat citra merek mereka, dan menghasilkan keputusan pembelian. Tujuan dari penelitian ini adalah untuk melihat bagaimana bauran komunikasi mempengaruhi keputusan pembelian pelanggan. Periklanan, penjualan pribadi, promosi penjualan, pemasaran langsung, dan hubungan masyarakat adalah lima aspek utama yang membentuk bauran komunikasi pemasaran. Dimana kelima bagian ini bersatu untuk memenuhi tujuan komunikasi pemasaran, yaitu meningkatkan citra produk, yang mengarah pada pembelian produk.
\end{abstract}

Kata Kunci : Pemasaran, Komunikasi Pemasaran, Pembelian 


\section{VISA: Journal of Visions and Ideas \\ Vol 1 No 3 (2021) 236-247 E-ISSN 2809-2058 P-ISSN 2809-2643 \\ DOI: $47467 /$ visa.v1i3.770}

\section{PENDAHULUAN}

Persaingan yang berkembang untuk minat pemasar dalam memahami perilaku pelanggan telah menjadi masalah utama dan salah satu bidang studi yang paling menantang dan menarik (Gupta 2016, 225). Menurut Mohir, Webb, dan Harris (2001), pertanyaan mendasar bagi pengambil keputusan bisnis di masa lalu adalah apakah mereka harus memperhatikan masalah selain profitabilitas perusahaan. Untuk mencapai tujuan perusahaan secara tepat dan benar, manajemen perusahaan harus memiliki rencana bisnis. Pemasaran adalah serangkaian tindakan luas yang bertujuan untuk mengidentifikasi, menetapkan harga, mempromosikan, dan mendistribusikan barang dan jasa yang memenuhi permintaan pelanggan saat ini dan pelanggan potensial (Swastha dan Irawan 2008, 5). Pemasaran adalah komponen penting dalam menentukan apakah sebuah perusahaan akan berhasil atau gagal. Tanggung jawab utama manajer pemasaran adalah menjual barang atau jasa dari perusahaan yang memiliki target pasar yang telah dipilih oleh organisasi.

Perlu juga dicatat bahwa karena pelanggan adalah pusat dari upaya pemasaran, memahami apa yang mereka butuhkan dan inginkan sangatlah penting. Pemahaman konsumen akan mengarahkan pemasar pada kebijakan pemasaran yang paling tepat, dan informasi produk yang bervariasi dapat dikomunikasikan kepada konsumen melalui komunikasi. Akibatnya, pengetahuan komunikasi yang lebih baik, khususnya komunikasi pemasaran, diperlukan untuk mempengaruhi perilaku pelanggan. Dalam kebanyakan kasus, komunikasi terjalin melalui interaksi dua pihak. Berbagai pihak dan kelompok, tanpa memandang usia atau jenis kelamin, dapat berkomunikasi satu sama lain.

Perusahaan menggunakan komunikasi pemasaran untuk menginformasikan, meyakinkan, dan mengingatkan pelanggan tentang barang dan merek yang mereka jual, baik secara langsung maupun tidak langsung (Kotler \& Keller, 2016, hlm. 580). Masyarakat percaya bahwa komunikasi pemasaran terpadu akan muncul dalam konteks media baru seperti televisi digital dan telepon seluler, serta lingkungan pasar, yang meliputi peningkatan daya saing global dan kemajuan teknologi yang pesat (Kitchen dan Burgmann, 2010).

Banyak sekali kesulitan yang akan menghambat keberhasilan suatu proses komunikasi jika komunikasi tidak semulus yang diharapkan. Ini bisa melibatkan fakta bahwa pesan yang dikirim dapat ditafsirkan dalam berbagai cara, menghasilkan banyak dampak dan tindakan. Selain pesan, hambatan dan gangguan komunikasi dapat disebabkan oleh komunikator, komunikan, dan pemilihan media. Oleh karena itu, diperlukan pemahaman yang lebih mendalam tentang komunikasi, khususnya komunikasi pemasaran dalam hal membentuk perilaku konsumen, karena hampir semua organisasi, baik yang bersifat profit maupun nonprofit, serta bisnis individu, saat ini menggunakan berbagai bentuk komunikasi pemasaran. untuk mempromosikan apa yang mereka tawarkan untuk mencapai tujuan 


\section{VISA: Journal of Visions and Ideas \\ Vol 1 No 3 (2021) 236-247 E-ISSN 2809-2058 P-ISSN 2809-2643 \\ DOI: $47467 /$ visa.v1i3.770}

perusahaan. dan juga agar pelanggan berperilaku dengan cara yang dapat diprediksi.

Konsumen mengevaluasi berbagai faktor saat membuat keputusan pembelian untuk memenuhi permintaan mereka akan barang dan jasa. Keputusan pembelian dibuat sebagai bagian dari proses perilaku konsumen, yang didefinisikan sebagai aktivitas individu yang secara aktif terlibat dalam memperoleh dan mengkonsumsi barang atau jasa yang tersedia. Calon pelanggan akan mengidentifikasi semua solusi yang dapat memecahkan masalah permintaan mereka dengan hati-hati dan obyektif memeriksa pilihan yang tersedia dan menentukan keuntungan dan kerugian sebelum membuat keputusan pembelian.

\section{KAJIAN PUSTAKA}

\section{Pemasaran}

Proses, metode, atau tindakan pemasaran suatu produk dikenal sebagai pemasaran. Manajemen pemasaran adalah proses penentuan perencanaan dan fungsi produk, penetapan harga, promosi, dan distribusi desain produk dalam bentuk barang dan jasa untuk memenuhi tujuan perusahaan, seperti laba dan pertumbuhan.

Berdasarkan konsep ini, pemasaran dapat didefinisikan sebagai suatu sistem dan proses sosial yang melibatkan orang dan kelompok dalam pengembangan, penawaran, dan pertukaran produk dan fungsinya dengan pihak lain untuk memenuhi kebutuhan dan keinginan mereka. Tujuan pemasaran adalah untuk memastikan bahwa suatu produk mencapai pembeli dalam kondisi baik. Komunikasi pemasaran yang berfungsi sebagai informasi, persuasif, dan motivasi, oleh karena itu mempengaruhi rute distribusi ke klien, sangat penting agar produk mencapai pelanggan secara efisien.

\section{Bauran Pemasaran}

Bauran pemasaran adalah seperangkat aspek yang saling berhubungan dalam pemasaran yang meliputi produk, harga, promosi, dan distribusi. Bauran pemasaran terdiri dari empat faktor yang terkait erat dan tidak dapat dipisahkan. Produk dirancang untuk memenuhi kebutuhan dan keinginan konsumen, harga yang ditetapkan berdasarkan manfaat produk dan segmentasi pasar, promosi atau komunikasi yang mengingatkan pelanggan akan ketersediaan produk, dan distribusi atau media yang digunakan untuk mendistribusikan produk yang dipilih berdasarkan karakteristik produk dan konsumen adalah empat elemen .

Keberhasilan suatu kampanye pemasaran sangat bergantung pada salah satu aspek kunci, yaitu promosi atau komunikasi pemasaran. Variabel promosi atau komunikasi pemasaran dalam bauran pemasaran menjadi semakin penting dalam beberapa tahun terakhir. Di era globalisasi ini bahkan dianggap bahwa pemasaran 


\section{VISA: Journal of Visions and Ideas \\ Vol 1 No 3 (2021) 236-247 E-ISSN 2809-2058 P-ISSN 2809-2643 \\ DOI: $47467 /$ visa.v1i3.770}

dan komunikasi pemasaran merupakan satu kesatuan yang tidak dapat dipisahkan dan tidak dapat dipisahkan.

\section{Komunikasi dalam Pemasaran}

Komunikasi pemasaran adalah pertukaran informasi antara produsen, distributor, dan konsumen yang terlibat dalam kampanye pemasaran. Dalam arti semua pihak yang terlibat dalam komunikasi pemasaran melakukan hal yang sama, dimulai dengan mendengarkan, menanggapi, dan berkomentar, dan akhirnya membentuk simbiosis mutualisme.

Komunikasi pemasaran bertindak sebagai penghubung antara produsen dan konsumen, membentuk simpul komunikasi yang memungkinkan produsen dan konsumen untuk bertukar informasi, sehingga menghasilkan hubungan yang saling menguntungkan. Komunikasi pemasaran juga dapat didefinisikan sebagai alat yang membantu produsen dan konsumen dalam bertransaksi, membina komunikasi agar transaksi dapat berlangsung secara berkelanjutan, menciptakan pemahaman bahwa telah terjadi transaksi yang saling menguntungkan, dan kemudian memproses komunikasi pemasaran sehingga transaksi menjadi lebih baik.

Singkatnya, komunikasi pemasaran adalah komunikasi dua arah antara produsen dan konsumen yang bertujuan untuk menginformasikan merek tentang atribut dan fungsinya, meningkatkan kesadaran merek dan citra merek, dan menghasilkan preferensi dan keputusan pembelian untuk merek tertentu dengan membina hubungan dan membangun pemahaman sampai terjadi transaksi yang berkelanjutan.

Strategi situasional, seperti periklanan kreatif, rasionalisasi karyawan pemasaran, manajemen hubungan pelanggan (CRM) yang efektif, mengorganisir acara dan sponsor untuk lebih dekat dengan pelanggan, dan menggunakan media alternatif dan interaktif dalam pemasaran langsung dan hubungan masyarakat, semuanya dapat membantu meningkatkan komunikasi pemasaran .

\section{Model Komunikasi Pemasaran}

Istilah "komunikasi" berasal dari bahasa Latin "komunikasi", yang berasal dari kata "communis", yang berarti "sama", di mana "sama" berarti "memiliki arti atau makna yang sama".

Komunikasi memainkan peran penting dalam periode globalisasi sebagai sarana penghubung yang tidak lagi dibatasi oleh geografi atau waktu. Komunikasi telah berkembang sedemikian rupa sehingga sekarang memungkinkan untuk berkomunikasi tidak hanya melalui suara, tetapi juga melalui grafik dan data. 


\section{VISA: Journal of Visions and Ideas \\ Vol 1 No 3 (2021) 236-247 E-ISSN 2809-2058 P-ISSN 2809-2643 DOI: $47467 /$ visa.v1i3.770}

Operasi komunikasi pemasaran perusahaan untuk suatu produk harus fokus pada pemenuhan dan kepuasan kebutuhan pelanggan.

Pembiasan makna dari substansi pesan dalam berkomunikasi merupakan masalah klasik dalam komunikasi pemasaran. Komunikasi yang tidak efektif antara komunikator dan komunikan, yang dapat disebabkan oleh masalah bahasa, psikologis, dan eksternal, menjadi sumber masalah ini. Langkah-langkah komunikasi yang efektif, seperti :

1) mengidentifikasi audiens sasaran;

2) tujuan komunikasi perencanaan;

3) mendefinisikan pesan;

4) pemilihan saluran komunikasi;

5) penetapan anggaran; dan

6) pemilihan penggunaan bauran komunikasi pemasaran, dapat membantu mengantisipasi permasalahan dalam komunikasi pemasaran.

\section{Bauran Komunikasi Pemasaran}

Periklanan, penjualan pribadi, promosi penjualan, hubungan masyarakat, dan pemasaran langsung adalah contoh faktor komunikasi pemasaran yang menyatu satu sama lain untuk mencapai tujuan pemasaran, seperti keputusan pembelian yang menghasilkan keuntungan bagi perusahaan.

Periklanan, penjualan pribadi, promosi penjualan, hubungan masyarakat, dan pemasaran langsung adalah bagian dari bauran komunikasi pemasaran. Di mana setiap elemen memiliki kepribadiannya sendiri dan serangkaian kekuatan dan keterbatasannya, elemen tersebut harus dipahami terlebih dahulu sebelum memutuskan rencana untuk dieksekusi, karena memiliki dampak yang signifikan terhadap anggaran perusahaan.

Sebelum memutuskan bagaimana menggunakan bauran komunikasi pemasaran, penting untuk memahami karakteristik masing-masing variabel, karena setiap variabel komunikasi pemasaran memiliki kepribadian dan serangkaian manfaat dan kekurangannya sendiri. Akibatnya, sebelum menetapkan strategi komunikasi pemasaran, organisasi harus menganalisis dan mempertimbangkan setiap bagian.

\section{Tujuan Komunikasi dalam Pemasaran}

Komunikasi yang efektif memiliki kemampuan untuk mengubah atau memperkuat perilaku yang telah dimodifikasi sebelumnya (Swastha dan Irawan, 2008). Komunikasi pemasaran konsumen berupaya mencapai tiga tahap transformasi (Soemanagara, 2012). Tahapan tersebut menurut Soemanagara (2012) adalah: 


\section{VISA: Journal of Visions and Ideas}

Vol 1 No 3 (2021) 236-247 E-ISSN 2809-2058 P-ISSN 2809-2643

DOI: 47467/visa.v1i3.770

1) Tahap perubahan pengetahuan, di mana pelanggan menyadari keberadaan suatu produk, tujuan pembuatannya, dan audiens yang dituju; akibatnya, pesan yang dikirimkan tidak memberikan informasi tambahan tentang produk.

2) Tahap kedua adalah tahap perubahan sikap; dalam perilaku konsumen, perubahan sikap ditentukan oleh tiga aspek, yaitu pengetahuan, sikap, dan perilaku, sebagaimana dijelaskan oleh Schiffman dan Kanuk sebagai tiga komponen perubahan sikap. Pergeseran sikap yang diinginkan, tentu saja, merupakan perubahan positif; pergeseran positif ini mengarah pada kesediaan konsumen untuk mencoba produk; semakin tinggi preferensi terhadap suatu produk, semakin besar kemungkinan untuk digunakan (beli).

3) Tahap ketiga adalah perubahan perilaku, yang dirancang agar pelanggan tidak beralih ke barang lain karena sudah terbiasa menggunakannya. Pesan tersebut dimaksudkan untuk mengilustrasikan mengapa produk ini masih menjadi produk terbaik jika dibandingkan dengan produk lain pada tahap modifikasi perilaku.

\section{Keputusan Pembelian}

Konsumen pada akhirnya harus membuat keputusan untuk membeli produk atau jasa berdasarkan kebutuhan atau keinginan mereka, menurut Griffin dan Ebert (2007:290). Korporasi harus memantau perilaku konsumen sebelum memutuskan mana yang akan dibeli. Memahami perilaku pelanggan terhadap keputusan pembelian yang didefinisikan sebagai persyaratan atau keinginan dapat digunakan sebagai strategi perusahaan untuk mencapai tujuan yang berfokus pada konsumen. Setiap pelanggan memiliki pendekatan unik untuk memutuskan apakah akan membeli produk atau layanan atau tidak. Bisnis yang bijak akan menyelidiki tahapan yang dilalui pembeli sebelum melakukan pembelian. Pada waktu tertentu, setiap pelanggan membuat penilaian yang berbeda mengenai pencairan, pembelian, dan penggunaan berbagai item dan merek. Umumnya niat beli memiliki pengaruh yang besar terhadap keputusan pembelian, yang bisa jadi karena pembeli membeli secara rasional berdasarkan faktor-faktor seperti harga (Daryanto, 2011: 94).

Keputusan pembelian adalah keputusan konsumen yang dipengaruhi oleh ekonomi finansial, teknologi, politik, budaya, produk, harga, lokasi promosi, bukti fisik, orang, dan proses, dengan tujuan membentuk sikap pada konsumen untuk memproses semua informasi dan menarik kesimpulan dalam berupa tanggapan yang muncul produk apa yang akan dibeli (Alma, 2011: 96). Konsumen akhir individu dan rumah tangga yang membeli produk dan jasa untuk konsumsi pribadi membuat keputusan pembelian konsumen (Kotler dan Keller, 2009:184).

Keputusan pembelian tertentu dipengaruhi oleh sifat pembeli dan proses pengambilan keputusan. Tugas pemasar adalah mencari tahu apa yang terjadi dalam benak pembeli, dimulai dengan adanya rangsangan eksternal dan diakhiri dengan 


\section{VISA: Journal of Visions and Ideas \\ Vol 1 No 3 (2021) 236-247 E-ISSN 2809-2058 P-ISSN 2809-2643 \\ DOI: $47467 /$ visa.v1i3.770}

keputusan pembelian pembeli. Perilaku konsumen akan mempengaruhi proses pengambilan keputusan dalam pembeliannya; prosesnya adalah strategi pemecahan masalah di mana pelanggan melalui lima tahap: deteksi masalah, pencarian informasi, penelitian alternatif, pengambilan keputusan, dan perilaku pascapembelian.

Pembahasan keputusan pembelian juga harus dimulai dengan pengakuan bahwa masalah keputusan pembelian bukanlah masalah yang mudah bagi calon konsumen, baik secara konseptual maupun analitis. Karena calon klien akan ragu untuk membelanjakan uang untuk produk yang tidak mereka kenal.

Keputusan pembelian, menurut beberapa uraian di atas, merupakan suatu proses yang menggabungkan informasi dan pilihan untuk mengevaluasi dua atau lebih tindakan alternatif dan memilih salah satunya.

Keputusan Pembelian Konsumen Dipengaruhi oleh Berbagai Faktor

Menurut Henry Assael dalam Tatik Suryani (2008), ada dua elemen yang mempengaruhi pengambilan keputusan dan sebagai hasilnya, respon konsumen:

1. Yang pertama adalah pemikiran konsumen itu sendiri, yang meliputi keinginan atau motivasi, persepsi, sikap, dan sifat konsumen seperti demografi, gaya hidup, dan kepribadian konsumen, yang semuanya mempengaruhi pengambilan keputusan.

2. Aspek kedua adalah dampak lingkungan, yang meliputi nilai budaya, pengaruh sub dan lintas budaya, kelas sosial ekonomi, kelompok tatap muka, dan situasi kritis lainnya. Komponen lingkungan ini akan memberikan informasi yang dapat mempengaruhi pengambilan keputusan konsumen melalui komunikasi.

\section{Perilaku pembeli}

Perilaku konsumen mengacu pada proses fisik mendapatkan barang dan jasa untuk konsumsi, serta proses pengambilan keputusan dan aktivitas yang dilakukan konsumen (Loudon dan Bitta, 1993). Perilaku konsumen mengacu pada aktivitas, proses, dan hubungan sosial yang dilakukan orang, kelompok, dan organisasi saat membeli, memanfaatkan, atau berinteraksi dengan produk, layanan, dan sumber lainnya (Zaltman dan Wallendorf, 1979 dalam Mangkunegara, 2015). Pemasar tidak hanya harus menganalisis perilaku pelanggan tetapi juga mengaitkannya dengan rencana pemasaran yang akan dihasilkan ketika mempelajari perilaku konsumen. Rencana pemasaran yang efektif berkisar pada apa yang diinginkan dan dibutuhkan pelanggan. Perusahaan yang dapat memahami perilaku konsumen akan menuai keuntungan yang signifikan karena mereka akan mampu membangun taktik pemasaran yang tepat yang akan memberikan tingkat kepuasan yang lebih tinggi daripada pesaing mereka. 


\section{VISA: Journal of Visions and Ideas \\ Vol 1 No 3 (2021) 236-247 E-ISSN 2809-2058 P-ISSN 2809-2643 \\ DOI: $47467 /$ visa.v1i3.770}

\section{METODE PENELITIAN}

Penelitian ini menggunakan metode studi pustaka (library research). Kutipan dalam tulisan ini didasarkan pada perspektif ahli dan penelitian sebelumnya tentang dampak komunikasi pemasaran terhadap keputusan pembelian konsumen.

\section{PEMBAHASAN DAN HASIL}

Tentunya dalam pengambilan keputusan konsumen, informasi yang diperoleh melalui komunikasi memegang peranan penting dalam membentuk persepsi konsumen, yang pada akhirnya akan bermuara pada perilaku konsumen. Komunikasi pemasaran bertanggung jawab untuk menginformasikan kepada masyarakat umum, khususnya konsumen sasaran, tentang keberadaan suatu produk di pasar. Pengaruh manajer pemasaran atas konten, ketepatan waktu, dan frekuensi informasi terkikis di era digital. Informasi tentang produk dan layanan juga berasal dari pasar di bawah paradigma baru. Data ini berasal dari pengalaman konsumen tertentu dan disebarluaskan melalui bauran promosi yang khas (Mangold dan Faulds, 2009). Kemampuan konsumen untuk berkomunikasi satu sama lain ditingkatkan oleh berbagai platform media sosial, banyak di antaranya sepenuhnya independen dari organisasi produksi, sponsor, atau agennya. Manajer pemasaran harus memahami kekuatan dan karakter kritis dari komentar pelanggan di media sosial dalam paradigma komunikasi baru.

Bauran promosi merupakan konsep komunikasi pemasaran yang umum digunakan untuk mengkomunikasikan pesan. Periklanan, penjualan tatap muka, promosi penjualan, publisitas, dan pemasaran langsung adalah lima bauran promosi (Kotler dan Keller 2016, 47f). Periklanan, menurut Swastha dan Irawan (2008), adalah presentasi dan promosi nonpersonal dari ide, barang, dan jasa yang dibayar oleh sponsor. Setiap organisasi harus mempertimbangkan banyak keputusan ketika mendefinisikan operasi periklanan, termasuk menentukan iklan mana yang harus didistribusikan ke pasar sasaran dan memilih media yang paling tepat. Penjualan tatap muka adalah ketika seorang wiraniaga berinteraksi dengan satu atau lebih calon pelanggan secara langsung untuk melakukan presentasi, menjawab pertanyaan, dan memesan (Kotler dan Keller 2016, hlm. 582). Penjualan tatap muka memiliki keuntungan dari tingkat kesadaran konsumen yang lebih tinggi, serta kemampuan untuk menyampaikan pesan (menjelaskan produk) secara lebih mendalam, dan yang paling penting, penjualan tatap muka digunakan untuk menghasilkan penjualan. . Satu-satunya cara untuk berkomunikasi langsung dengan calon pelanggan adalah melalui penjualan tatap muka.

Promosi konsumen (seperti sampel, diskon, dan hadiah), promosi perdagangan (seperti tunjangan iklan dan tampilan), serta promosi dan promosi perusahaan, menurut Kotler dan Armstrong (2018), adalah insentif jangka pendek untuk merangsang percobaan atau pembelian produk. sebuah produk atau layanan. 


\section{VISA: Journal of Visions and Ideas \\ Vol 1 No 3 (2021) 236-247 E-ISSN 2809-2058 P-ISSN 2809-2643 \\ DOI: $47467 /$ visa.v1i3.770}

force of sales Sementara itu, PR adalah berita atau bentuk komunikasi dari suatu perusahaan yang tidak memiliki konten apapun, baik yang menguntungkan maupun yang negatif. Dalam arti lain, publisitas adalah upaya untuk membangun dan memelihara hubungan positif antara organisasi dan masyarakat umum, yang meliputi pemilik perusahaan, karyawan, instansi pemerintah, distributor, dan pembeli potensial (Swastha dan Irawan 2008, hlm. 352).

Penggunaan bauran komunikasi pemasaran dapat meningkatkan jumlah konsumen, hal ini menunjukkan bahwa penggunaan komunikasi pemasaran suatu perusahaan mempengaruhi pilihan pembelian mereka. Bauran komunikasi pemasaran akan membantu meningkatkan citra merek, yang akan meningkatkan motivasi konsumen untuk membeli. Semakin agresif bauran komunikasi pemasaran, yang meliputi periklanan, penjualan pribadi, promosi penjualan, pemasaran langsung, dan hubungan masyarakat, digunakan, semakin tinggi citra merek, yang mengarah pada peningkatan insentif untuk membeli merek.

\section{KESIMPULAN}

Istilah "komunikasi pemasaran" mengacu pada jenis komunikasi yang mencoba memperkuat strategi pemasaran untuk menjangkau khalayak yang lebih besar. Artikel ini juga dapat dilihat sebagai upaya untuk meningkatkan loyalitas klien terhadap produk perusahaan, seperti barang dan jasa. Seorang pemasar harus memahami bahwa efektivitas strategi komunikasi pemasaran dapat diukur dengan jumlah penjualan produk atau uang tunai yang dihasilkan oleh penggunaan layanan oleh konsumen. Berdasarkan argumentasi di atas, dapat dinyatakan bahwa tanpa komunikasi, konsumen dan masyarakat secara keseluruhan tidak akan mengetahui keberadaan produk di pasar jika tidak memahami cara memperolehnya. Berbeda dengan komunikasi, dimana produsen atau perusahaan memutuskan media mana yang akan digunakan, bagaimana mengemas pesan tentang produk dan perusahaan, siapa yang menjadi sasaran dan siapa yang akan menjadi nara sumber ketika menginformasikan produk, segala sesuatu yang berhubungan dengan pemasaran akan lebih efektif. Jika pemasaran tepat sasaran, tentu perilaku konsumen yang diharapkan akan terwujud. Karakteristik pesan harus diperkuat dengan cara mendongkrak citra merek dan citra produsen agar memiliki tingkat loyalitas yang tinggi dalam konstruksi sikap dan perilaku konsumen. Iklan, wiraniaga, papan nama, toko, pajangan, pengemasan produk, sampel produk gratis, kupon, hadiah, dan teknik komunikasi pemasaran lainnya adalah contohnya.

Isi pesan pemasaran memiliki dampak signifikan pada bagaimana pelanggan mengevaluasi suatu produk. Akibatnya, komunikator harus mampu menyusun pesan persuasif. Pesan tersebut, secara teori, harus menarik perhatian orang, menggugah rasa ingin tahu mereka, menggugah keinginan mereka, dan membujuk mereka untuk membeli barang tersebut. Kebutuhan untuk memahami perubahan 


\section{VISA: Journal of Visions and Ideas \\ Vol 1 No 3 (2021) 236-247 E-ISSN 2809-2058 P-ISSN 2809-2643 \\ DOI: $47467 /$ visa.v1i3.770}

perilaku pelanggan di era disrupsi juga merupakan topik utama yang harus dimiliki seorang pemasar untuk mengikuti laju transformasi konsumen yang serba cepat.

\section{DAFTAR PUSTAKA}

Amir T., 2005. Dinamika Pemasaran Jelajahi dan Rasakan. PT RajaGrafindo Persada, Jakarta, h. 212.

Alma, B. 2011. Manajemen Pemasaran dan Pemasaran Jasa. Alfabeta. Bandung.

Ardial dan Yustina I. 2011. Pengaruh Komunikasi Pemasaran Terhadap Peningkatan Jumlah Nasabah Asuransi Bumi Asih Jaya Medan. Jurnal Ilmu Sosial, April 2011, h. 8.

Diwatia F. dan Santosob T.I. 2015. Pengaruh Strategi Integrated Marketing Communication (IMC) terhadap Keputusan Membeli Konsumen pada Bisnis Tour \& Travel di Wilayah Daerah Istimewa Yogyakarta. Jurnal EBBANK, Vol.6, No. 2 , Hal.33-54 , Desember 2015, h. 34.

Daryanto. 2011. Sari Kuliah Manajemen Pemasaran. PT Sarana Tutorial Nurani Sejahtera. Bandung 


\section{VISA: Journal of Visions and Ideas}

\section{Vol 1 No 3 (2021) 236-247 E-ISSN 2809-2058 P-ISSN 2809-2643 DOI: 47467/visa.v1i3.770}

Natalia P. dan Mulyana M. 2014. Pengaruh Periklanan dan Promosi Penjualan terhadap Keputusan Pembelia. Jurnal Ilmiah Manajemen Kesatuan Vol.2 No.2, 2014, h. 3.

Gupta, R. (2016). Disruptive Marketing and Brand Building-A Case Study of Patanjali, Ayurveda Limited. Advances in Economics and Business Management (AEBM), 225-231.

Griffin, R. W. dan Ebert, R. J. 2007. Bisnis. Edisi kedelapan. Erlangga. Jakarta.

Imelda S. 2013. Pengaruh Keputusan Bauran Promosi terhadap Pengambilan Keputusan Pembelian Nomor Perdana Telkom Flexi di Kota Banjarmasin. Jurnal Wawasan Manajemen, Vol. 1, Nomor 2, Juni 2013, h. 260.

Kotler, P., \& Keller, K. L. (2016). Marketing Management Global Edition (15th ed.). United States of America: Pearson Education Limited.

Kitchen, P. J., \& Burgmann, I. (2010). Integrated Marketing Channel. Wiley International Encyclopedia of Marketing, 1-23.

Kotler, P. dan K. L. Keller. 2009. Marketing Manajement (13th ed). Upper Saddle River. New Jersey

Loudon, D. L., \& Bitta, A. D. (1993). Consumer Behavior: Concept and Applications. The United State of America: By McGraw Hill Inc.

Mangold, W., \& Faulds, D. (2009). Social media: The new hybrid element of the promotion mix. Business Horizons Elsevier, 357-365.

Pratiwi M.P., Suwendra I.W., dan Nyoman Yulianthini N.N. 2015. Pengaruh Strategi Komunikasi Pemasaran terhadap Keputusan Pembelian Sepeda Motor Honda. e-Journal Bisma Universitas Pendidikan Ganesha Jurusan Manajemen Vol 3 Tahun 2015, h. 9

Sarjita. 2016. Komunikasi Pemasaran dalam Menghadapi Persaingan Pasar. JBMA Vol. III, No. 1, Maret 2016, h. 61.

Swastha, B., \& Irawan. (2008). Manajemen Pemasaran Modern. Yogyakarta: Liberty Yogyakarta.

Soemanagara, R. (2012). Strategic Marketing Communication: Konsep Strategis dan Terapan. Bandung: Alfabeta.

Yusniar. 2013. Analisis Kualitas Pelayanan dan Komunikasi Pemasaran terhadap Kepuasan Konsumen pada CV. Baroena di Desa Uleu Reuleung Kec. Dewantara 


\section{VISA: Journal of Visions and Ideas}

Vol 1 No 3 (2021) 236-247 E-ISSN 2809-2058 P-ISSN 2809-2643

DOI: 47467/visa.v1i3.770

Kab. Aceh Utara. Jurnal visioner \& Strategi Volume 2, Nomor 1, Maret 2013, h. 97. 